\title{
Editor-in-Chief Editorial Board
}

E.B. Hendrick, Toronto Developmental Anatomy Neuropathology

Managing Editor D.G. McLone, Chicago, 111. L.B. Rorke, Philadelphia, Pa.

D.H. Reigel, Pittsburgh, Pa. R.J. Lemire, Seattle, Wash. I. Becker, Toronto

Associate Editors J. Warkany, Cincinnati, Ohio F. Gilles, Los Angeles, Calif. I

R.L. McLaurin, Cincinnati, Ohio Pediatric Neurology M. Norman, Vancouver

D.G. McLone, Chicago, 111. J.J. Volpe, St. Louis, Mo. Neuroimaging

T.P. Naidich, Miami, Fla. M. Johnston, Ann Arbor, Mich. T.P. Naidich, Miami, Fla.

L.B. Rorke, Philadelphia, Pa. H. Singer, Baltimore, Md. B. Kendall, London

JJ. Volpe, St. Louis, Mo. $\quad$ D. Stumpf, Chicago, 111. C. Raybaud, Marseille

Pediatric Neuro-Oncology R.A. Zimmerman,

R.J. Packer, Philadelphia, Pa. Philadelphia, Pa.

C.C. Bailey, Leeds Pediatrics

L.E. Kun, Memphis, Tenn. D.B. Shurtleff, Seattle, Wash.

T. Tomita, Chicago, 111. Medical Media

Pediatric Neuro-Ophthalmology J. Vetter, Pittsburgh, Pa.

EC. Chu, St. Louis, Mo.

C.S. Hoyt, San Francisco, Calif.

Pediatric Neuropsychology

H.S. Levin, Galveston, Tex.

Pediatric Neurosurgery

R.L. McLaurin, Cincinnati, Ohio

D. Bruce, Dallas, Tex.

P. Chapman, Boston, Mass.

M. Edwards, San Francisco, Calif.

R. Humphreys, Toronto

J. Venes, Ann Arbor, Mich.

M. Walker, Salt Lake City, Utah 
S. Karger $\cdot$ Medical and Scientific Publishers

Basel $\cdot$ München $\cdot$ Paris $\cdot$ London $\cdot$ New $\mid$ York $\llbracket$ New Delhi $\cdot$ Bangkok $\square$ Singapore $\cdot$ Tokyo $\square$ Sydney

Drug Dosage

The authors and the publisher have exerted every effort to ensure that drug selection and dosage set forth in this text are in accord with current

recommendations and practice at the time of publication. However, in view of ongoing research, changes in government regulations, and the constant flow of information relating to drug therapy and drug reactions, the reader is urged to check the package insert for each drug for any change in indications and dosage and for added warnings and precautions. This is particularly important when the recommended agent is a new and/or infrequently employed drug. 
All rights reserved.

No part of this publication may be translated into other languages, reproduced or utilized in any form or by any means, electronic or mechanical, including photocopying, recording, microcopying, or by any information storage and retrieval system, without permission in writing from the publisher or, in the case of photocopying, direct payment of a specified fee to the Copyright Clearance Center (see 'Information for Readers and Subscribers').

(c) Copyright 1988 by S. Karger AG, P.O. Box, CH-4009 Basel (Switzerland) Printed in Switzerland by Werner Druck AG, Basel 
Contents Vol. 14,1988

No. 1 
No. 2

The Editor-in-Chief Speaks

Matson Lecture 1988

Hendrick, E.B 


\section{Neuro-Oncology}

Ependymomas in Children Kun, L.E.; Kovnar, E.H.: 


\section{Original Papers}

'Slit-Ventricle Syndrome': Etiology and Treatment

Epstein, F.; Lapras, C; Wisoff, J.H 5

Epithelioid Hemangioendothelioma of the Central Nervous System. Immunohistochemical and Ultrastructural Observations of a Pediatric Case Taratuto, A.L.; Zurbriggen, G.; Sevlever, G.; Saccoliti, M. 11

Sex Hormone Receptors in a Congenital Meningioma

Carter, D.A.; Hollenberg, R.D

15

Role of Magnetic Resonance Imaging and Three-Dimensional

Computerized Tomography in Craniovertebral Junction

Anomalies

Pappas, C.T.E.; Rekate, H.L 18

Choroid Plexus Papillomas of Neonates, Infants and Chil

dren

Tomita, T.; McLone, D.G.; Flannery, A.M

Computer-Assisted Stereotactic Biopsy of Intracranial Lesions in Pediatric Patients

Davis, D.H.; Kelly, P.J.; Marsh, W.R.; Kail, B.A.; Goerss,

S.J $\quad 31$

The Neuro Image Quiz, Questions

37

Historical Vignettes

Josef Warkany's Contributions to the Evolution of Neuro-

teratology

Lemire, R.J

38

Clinical Pathological Correlations

Progressive Neurological Deterioration in a 14 -Year-Old

Girl

Berman, P.H.; Davidson, G.S.; Becker, L.E

Case Report

Sylvian Fissure Meningioma in a Child: Case Report and Review of the Literature

Silbergeld, D.; Berger, M.; Griffin, B 


\section{Original Papers}

Significance of Basal Ganglia Calcification on Computed Tomography in Children Legido, A.; Zimmerman, R.A.; Packer, R.J.; Bilaniuk, L.T.;

Siegel, K.R.; D'Angio, G 64

Parietal Cephaloceles: Radiographic and Magnetic Resonance Imaging Evaluation

Curnes, J.T.; Oakes, W.J

Ventricular Volume Regulation: A Mathematical Model and Computer Simulation

Rekate, H.L.; Brodkey, J.A.; Chizeck, H.J.; El Sakka, W.;

Ko, W.H 77

Resistance of the Foramen of Monro

Rekate, H.L.; Williams, F.C., Jr.; Brodkey, J.A.; McCor-

mick, J.M.; Chizeck, H.J.; Ko, W 85

Diastematomyelia - A 40-Year Experience

Gower, D.J.; Del Curling, O.; Kelly, D.L., Jr.; Alexander,

E., Jr $\quad 90$

Neurogenic Arthrogryposis multiplex congenita: Clinical and

Muscle Biopsy Findings

Adams, C; Becker, L.E.; Murphy, E.G 97

\section{Case Reports}

Brainstem Glioma with Multiple Intraspinal Metastases dur ing Life: Case Report and Review of the Literature

Silbergeld, D.; Berger, M.; Griffin, B.; Bleyer, A.; Geyer, R.; Milstein, J.; Eskridge, J 103

Diastematomyelia Associated with Ectopic Renal Tissue

Gaskill, S.J.; Kagen-Hallett, K; Marlin, A.E 108

Announcements 112

The Neuro Image Quiz, Answers 
Contents

No. 3 


\section{No. 4}

Editorial 113

Original Papers

Cerebral Hemiatrophy - Correlation of Human with Animal

Experimental Data

Ford, L.; de Courten-Myers, G.M.; Mandybur, T.; Myers,

R.E 114

Use of the 'H' Reflex Recovery Curve in Selective Posterior Rhizotomy

Storrs, B.B.; Nishida, T 120

Clinical Pathological Correlations

Rapid Deterioration in a Three-Year-Old with Left Hemi-paresis

Ashwal, S.; Rorke, L.B.; Epstein, M.A.; Sladky, J.L.; Zim-

mermann, R.A 124

Case Reports

Choroid Plexus Carcinoma of the Fourth Ventricle. Report of a Case in an Infant

Griffin, B.R.; Stewart, G.R.; Berger, M.S.; Geyer, J.R.;

O'Dell, M.; Rostad, S 134

Pituitary Stalk Agenesis: Magnetic Resonance Imaging of

'Ectopic Posterior Lobe' with Surgical Correlation

Kaufman, B.A.; Kaufman, B.; Mapstone, T.B 140

Abstracts

International Symposium on Pediatric Neuro-Oncology

Seattle, Wash., June 1-3, 1989

145

1(

Announcements 


\section{Original Papers}

Temporal-Lobe Abnormalities in Thanatophoric Dysplasia

Knisely, A.S.; Ambler, M.W 169

Neonatal Cerebral Venous Thrombosis

Hanigan, W.C.; Tracy, P.T.; Tadros, W.S.; Wright, R.M.. 177 Symptomatic Chiari I Malformation in Childhood: A Report of 7 Cases

Dauser, R.C.; DiPietro, M.A.; Venes, J.L

Planning Ventriculoperitoneal Shunts in Infants and Small

Children

Bridges, N.; Rifkinson-Mann, S.; Handler, M.; Epstein, F. 191 Relationship between Intracranial and Sagittal Sinus Pressure in Normal and Hydrocephalic Dogs

Olivero, W.C.; Rekate, H.L.; Chizeck, H.J.; Ko, W.;

McCormick, J.M 196

The Neuro Image Quiz, Questions

Neuro-Oncology

Management of Craniopharyngiomas in Children

Tomita, T204

Clinical Pathological Correlations

Posterior Fossa Mass and Hydrocephalus in a 7-Month-Old

Boy

Schut, L; Gilles, F.; Rorke, LB

212

Technical Note

A Technique for Removal of an Adherent Ventricular Cath

eter

Chambi, I.; Hendrick, E.B 216 


\section{Contents}


No. 5 


\section{No. 6}

Editorial 221

Original Papers

Neuronal Migration Abnormalities Can Still Be Diagnosed by

Computed Tomography!

Buckley, A.R.; Flodmark, O.; Roland, E.H.; Hill, A. . . 222 Development of the Human Motor Trigeminal Nucleus

Hamano, S.; Goto, N.; Nara, T

Heterogeneity of Nemaline Myopathy. A Follow-Up Study of

13 Cases

Shahar, E.; Tervo, R.C.; Gordon Murphy, E

236

Aggressive Physiologic Monitoring of Pediatric Head Trauma

Patients with Elevated Intracranial Pressure

Kasoff, S.S.; Lansen, T.A.; Holder, D.; San Filippo, J. . . 241 Brain Abscess after Dilatation of Esophageal Stricture

Lui, T.-N.; Lee, S.-T.; Chang, C.-N.; Wang, H.-S 250

Radiation Exposure to the Ocular Lens during CT Scanning

Storrs, B.B.; Byrd, S.E 254

Patient Data System for Monitoring Shunts

Frank, E.; Su, E.; Smith, K 258

Conservative Management of Thrombosed Vein of Galen

Malformations. Report of Two Cases and a Review of the

Literature

Zampella, E.J.; Aronin, P.A.; Odrezin, G.T.; Duvall, E.R. 264 An Unusual Syndrome of Pediatric Brainstem Trauma (With

1 color plate)

Galyon, D.D.; Winfield, J.A 272

Announcement 257 


\section{Original Papers}

Benign Ependymomas of the Posterior Fossa in Childhood

Tomita, T.; McLone, D.G.; Das, L.; Brand, W.N 277

Hyperbaric Oxygen in the Treatment of Elevated Intracranial

Pressure after Head Injury

Brown, J.A.; Preul, M.C.; Taha, A

286

Pediatric Cerebral Abscess

Moss, S.D.; McLone, D.G.; Arditi, M.; Yogev, R 291

Gait Analysis of Cerebral Palsy Children before and after

Rhizotomy

Vaughan, C.L.; Berman, B.; Staudt, L.A.; Peacock, W.J. . 297 Fetal Neuropathology of Proliferative Vasculopathy and Hydranencephaly-Hydrocephaly with Multiple Limb

Pterygia

Norman, M.G.; McGillivray, B 301

Clinical Pathological Correlations

Dementia, Rigidity and Seizures in an Adolescent Boy

Butler, I.J.; Rouah, E.; Pearl, P 307

Case Reports

Spinal Cord Injury in I-Cell Disease

Goodman, M.L.; Pang, D 315

Postradiation Meningioma in a Child

Balasubramaniam, C; Armstrong, D.; Cheek, W.; Laurent, J. 319

Announcement 324

Author Index $\quad 325$

Subject Index $\quad 326$ 